\title{
PENGARUH PANDEMI COVID 19 TERHADAP MARAKNYA KASUS PERCERAIAN DI BERBAGAI PENGADILAN AGAMA
}

\author{
I Gede Hartadi Kurniawan, Zulfikar Judge, Fitria Olivia, Agus Suprayogi, Sri Redjeki \\ Slamet, Ade Hari Siswanto, Henry Arianto \\ Fakultas Hukum, Universitas Esa Unggul, Jakarta \\ Jalan Arjuna Utara Tol Tomang Kebon Jeruk, Jakarta - 11510 \\ igedehartadi@gmail.com
}

\begin{abstract}
The Covid 19 pandemic has brought many influences to all aspects of people's lives around the world, including in Indonesia. It all started with the enactment of the status of Large-Scale Social Restrictions (PSBB) in various regions in Indonesia which resulted in the closure of various types of businesses that were not included in the types of businesses that were allowed to operate during the PSBB period. Almost the same thing also happens in various parts of the world, so that it greatly influences both directly and indirectly on export and import trade activities. Lack of orders for industrial products from abroad or imported materials as raw materials for production, has resulted in a wave of job terminations or reduction of employees in various types of industries, resulting in household economic problems for employees from various industries and factories, leading to a lawsuit. divorce due to family economic factors. With so many divorce cases in Indonesia during the COVID-19 pandemic, it automatically affects the number of new widowers or widows as a result of the divorce proceedings. Therefore, the purpose of this community service activity is to receive input from webinar participants to find solutions to the consequences of the divorce process and related to Law number 1 of 1974 concerning Marriage which should need to be revised again in several articles, because it is not in accordance with provisions in various religions recognized in Indonesia, and specifically regarding the provisions regarding marriage in the teachings of the Islamic Religion. The method of implementing this community service is to use the online seminar method or called a Webinar
\end{abstract}

Keywords: divorce, pandemic, marriage

\begin{abstract}
Abstrak
Pandemi Covid 19 telah membawa begitu banyak pengaruh bagi seluruh sendi kehidupan masyarakat di seluruh dunia, tidak terkecuali di Indonesia. Semua bermula dari diberlakukan status Pembatasan Sosial Berskala Besar (PSBB) di berbagai wilayah di Indonesia yang bermuara dengan ditutupnya berbagai jenis usaha yang tidak masuk ke dalam jenis usaha yang diperbolehkan beroperasi selama masa PSBB. Hal yang hampir sama juga terjadi di berbagai penjuru dunia, sehingga sangat berpengaruh baik secara langsung ataupun tidak langsung terhadap kegiatan perdagangan ekspor dan impor. Kurangnya pemesanan barang hasil industri dari luar negeri ataupun bahan -bahan impor sebagai bahan baku produksi, mengakibatkan gelombang Pemutusan Hubungan Kerja ataupun pengurangan karyawan di berbagai jenis industri, sehingga mengakibatkan problem ekonomi rumah tangga karyawan dari berbagai industri dan pabrik-pabrik, sehingga bermuara ke gugatan perceraian akibat faktor ekonomi keluarga. Dengan banyaknya kasus perceraian di Indonesia di masa pandemi covid 19, maka secara otomatis berdampak kepada banyaknya duda atau janda baru sebagai akibat hasil dari proses siding perceraian. Oleh karenanya ,tujuan dari kegiatan pengabdian masyarakat ini supaya dapat menerima masukan dari peserta webinar untuk ditemukan solusi terhadap akibat dari proses perceraian dan terkait dengan Undang-Undang nomor 1 tahun 1974 tentang Perkawinan yang seharusnya perlu di revisi kembali di beberapa pasalnya, karena tidak sesuai dengan ketentuan dalam berbagai agama yang diakui di Indonesia, dan secara khusus tentang ketentuan mengenai perkawinan di dalam ajaran Agama Islam.Adapun metode pelaksanaan pengabdian masyarakat ini adalah menggunakan metode seminar secara daring atau dinamakan Webinar
\end{abstract}

Kata kunci : perceraian, pandemi, perkawinan

\section{Pendahuluan}

Tidak ada yang menyangka bahwa kejadian awal penularan virus Corona pada akhir tahun 2019 di Kota Wuhan, Republik Rakyat China , akan menjadi pandemi secara global di seluruh dunia ,
Pandemi virus Corona atau yang juga dinamakan Covid 19 yang menyebar secara massif ke seluruh dunia, pada akhirnya secara otomatis menyentuh kegiatan perekonomian seluruh dunia. Protokol jaga jarak serta kebijakan lockdown di berbagai negara, 
tidak terkecuali di Indonesia dengan kebijakan Pembatasan Sosial Berskala Besar (PSBB), secara langsung ataupun tidak langsung sangat berpengaruh dengan aktivitas perekonomian di Indonesia. Penutupan pusat pusat perbelanjaan serta sangat berkurangnya kegiatan ekspor impor, tentunya berpengaruh terhadap aktivitas pekerja atau buruh buruh di berbagai industri. Hal ini membawa implikasi terhadap penghasilan yang didapat oleh pekerja dan sudah tentu istri berikut anaknya pekerja tersebut di rumah. Ketika seorang pekerja mengalami nasib diberhentikan atau di rumahkan dari industri tempatnya bekerja, sudah tentu pekerja tidak membawa hasil atau memberikan nafkah materi untuk istri berikut anaknya di rumah. Hal ini lah sebagai sebab berbagai kasus gugatan perceraian bermotif atau berlatar belakang ekonomi, sehingga di masa pandemi covid 19, hampir semua Pengadilan Agama dipenuhi oleh berbagai pasangan yang melakukan gugatan perceraian baik oleh pihak istri ataupun suami. Kegiatan pengabdian masyarakat ini dilakukan dengan metode daring dan bertujuan untuk dapat mencari solusi perubahan berbagai aturan di dalam Undang-Undang nomor 1 tahun 1974 tentang Perkawinan, untuk mengantisipasi berbagai akibat dari maraknya kasus perceraian di masa pandemi covid 19 .

\section{Metode Pelaksanaan}

Pelaksaaan kegiatan Abdimas dilakukan pada tanggal 15 Oktober 2020 dengan metode Web Seminar (WEBINAR ) dengan pelaksana Abdimas yaitu :

1. I Gede Hartadi Kurniawan, SE,SH,M.Kn ( Ketua)

2. Zulfikar Judge ,SH,M.Kn ( Anggota)

3. Fitria Olivia,SH,MH (Anggota)

4. Agus Suprayogi,SH,MH (Anggota)

5. Sri Rejeki Slamet,SH,MH (Anggota)

6. Ade Hari Siswanto,SH,MH (Anggota)

Pelaksanaan Webinar dilaksanakan dengan meng-install aplikasi zoom di note book serta memasukkan email sebagai user id dan password di dalam aplikasi zoom. Di dalam aplikasi zoom meeting, host berikut co-host dalam meeting Webinar tersebut wajib tersedia dan LPPM bertindak sebagai host serta saya sebagai narasumber bertindak sebagai co host. Host berikut Co host dapat melakukan untuk menerima peserta meeting webinar serta melakukan penyajian materi berikut data ke dalam materi webinar. Penyajian materi untuk bahan seminar di dalam perangkat aplikasi zoom tersebut tidak berbeda jauh esensinya dengan penyajian data dengan menggunakan proyektor yang dihubungkan ke laptop pada seminar yang dilakukan dengan metode seminar tatap muka. Hanya hal yang sangat berbeda bahwa penyajian data tersebut dilakukan langsung ke dalam laptop masing-masing peserta, dibandingkan dengan penyajian data materi pada seminar tatap muka yang disajikan pada layar proyektor . Keuntungan dari pelaksanaan Webinar yaitu bahwa pembawa acara, nara sumber berikut peserta dapat berada di rumah atau kantor masingmasing, dan hal ini sesuai dengan situasi pandemi Covid 19 yang sedang berlangsung pada saat ini, ketika masyarakat harus menghindari kerumunan dan bersama sama menjaga jarak antara satu dengan yang lain.

\section{Hasil dan Pembahasan}

Sebagai akibat bertambahnya masyarakat yang tertular virus Covid 19, dan di beberapa tertentu terdapat zona merah dalam rantai penularan, sehingga secara langsung ataupun tidak langsung, terjadi banyaknya kasus Pemutusan Hubungan Kerja , karyawan dirumahkan, pengurangan jam kerja karyawan yang terkait erat terhadap lemahnya posisi karyawan terhadap kebijakan pengurangan karyawan disaat banyaknya perusahaan yang mengalami kesulitan penjualan produk akibat pemberlakuan Pembatasan Sosial Berskala Besar baik transis ataupun ketat. Hal ini tentunya berakibat secara langsung terhadap karyawan itu sendiri berikut keluarganya baik istri ataupun anak-anak dari karyawan tersebut.

Tujuan awal dalam mencapai keluarga yang sakinah, mawaddah dan warohmah di dalam perkawinan sulit tercapai akibat kesulitan faktor ekonomi yang terjadi di tengah situasi pandemi Covid 19. Kebutuhan dasar dari setiap manusia secara alami adalah kebutuhan sandang, pangan dan papan. Apabila 3 Kebutuhan dasar tersebut tidak terpenuhi, maka sulit bagi sebuah keluarga untuk mempertahankan bahtera rumah tangga di tengah kebutuhan untuk bertahan hidup, terlebih lagi di tengah kesulitan hidup akibat kebutuhan dasar hidup manusia yang tidak pernah berkurang

Angka Perceraian di Pulau Jawa meningkat akibat pandemi COVID-19. Direktorat Jenderal Badan Pengadilan Mahkamah Agung Republik Indonesia (Dirjen Badilag MARI) Aco Nur menduga hal itu dilatarbelakangi faktor ekonomi.

"Akibat COVID-19 kan banyak di-PHK, sehingga ekonomi nggak berjalan lebih baik. Hal itu membuat ibu-ibu nggak mendapat jaminan dari suaminya," ujar Aco di Jakarta, Jumat (28/8/2020).

Mayoritas penggugat cerai yang masuk dalam daftar pengadilan agama adalah istri, yang dilandasi faktor ekonomi. Kasus perceraian umumnya terjadi di Pulau Jawa, khususnya di Provinsi Jawa Barat, kemudian di Kota Semarang dan Surabaya.Aco memaparkan saat awal penerapan PSBB pada April dan Mei 2020, perceraian di 
Indonesia di bawah 20 ribu kasus, namun pada Juni dan Juli 2020, jumlah perceraian meningkat menjadi 57 ribu kasus( DETIK NEWS 28 AGUSTUS 2020 https $/ /$ news.detik.com/berita/d-5150980/perceraiandi-pulau-jawa-meningkat-gegara-pandemi-covid-19)

Provinsi Jawa Barat adalah salah satu daerah dengan angka perceraian tertinggi di Indonesia. Berdasarkan data Badan Pusat Statistik (BPS) dalam Statistik Indonesia 2018, secara berturut-turut Provinsi Jawa Timur, Jawa Barat dan Jawa Tengah menempati urutan pertama, kedua dan ketiga di Indonesia dalam jumlah kasus perceraian di 2017.Bila merujuk pada laman layanan Si Kabayan Pengadilan Tinggi Agama (PTA) Jabar, setidaknya hingga Senin (7/9/2020) terdapat total 51.646 kasus cerai gugat dan 17.397 cerai talak yang telah diajukan dan diproses sejak Januari 2020 di PTA Jabar

(https $: /$ ayobandung.com/read/2020/09/08/127042/p erceraian-di-jabar-tinggi-selama-pandemikomunikasi-jadi-sorotan).

Dengan begitu maraknya Kasus perceraian di berbagai Pengadilan Agama, khusus nya di Pulau Jawa dengan kasus tertinggi berada di Provinsi Jawa Barat, maka dipastikan juga bertambahnya Duda atau Janda baru sebagai akibat kasus perceraian .Problematika bertambahnya Duda atau Janda baru ditambah dengan anak-anak dibawah umur, akan menambah beban kembali bagi orang tua si duda atau janda tersebut, terlebih khusus terhadap kehidupan selanjutnya duda atau janda tersebut setelah bercerai.

Dengan situasi kondisi dan ekonomi yang semakin sulit di masa pandemi, maka situasi kemungkinan besar akan bertambah tidak baik juga ketika para pihak yang sudah bercerai tersebut ketika kembali ke orang tua masing-masing, terutama para janda dari hasil perceraian akibat situasi pandemi covid 19. Dengan semakin rumitnya faktor ekonomi yang dialami oleh sebagian besar pasangan yang bercerai, maka banyak pula yang mengambil jalan pintas demi memenuhi kebutuhan ekonomi nya dengan menjadi Pekerja Seks Komersial (PSK) di berbagai tempat akibat kebutuhan ekonomi yang mendesak dan terbukti bahwa kita sering lihat beritanya di berbagai media.

Pada saat ini, klausula pernikahan di Indonesia masih menggunakan Undang-Undang nomor 1 tahun 1974 tentang Perkawinan sebagai rujukan bagi setiap warga negara untuk ditaati yang ingin melangsungkan perkawinan. UU nomor 1 tahun 1974 merupakan suatu Undang-Undang yang seharusnya direvisi untuk memenuhi tuntutan jaman di tengah perkembangan jumlah penduduk dan perkembangan kehidupan perekonomian masyarakat yang semakin sulit, dan terlebih lagi bertentangan dengan berbagai hal yang tertuang di Kitab Suci Al Qur'an

Kementerian Dalam Negeri merilis data kependudukan semester I/2020. Hasilnya jumlah laki-laki lebih banyak dibandingkan dengan perempuan. Kementerian Dalam Negeri melalui Direktorat Jenderal Kependudukan dan Pencatatan Sipil setiap tahun menerbitkan sebanyak dua kali data kependudukan nasional. Berdasarkan ata kependudukan yang dikeluarkan Direktorat Jenderal Kependudukan dan Pencatatan Sipil Kemendagri per 30 Juni sebanyak 268.583.016 jiwa.

Jumlah itu terdiri atas 135.821 .768 penduduk laki-laki atau naik sebesar 0,71 persen dibanding tahun lalu. 132.761.248 Penduduk perempuan atau naik 0,82 persen dibanding tahun lalu. (https://www.solopos.com/penduduk-laki-lakiindonesia-lebih-banyak-dari-perempuan-inidatanya1075573\#: :text=Indonesia\% 20L...

,Penduduk\% 20Laki\%2DLaki\%20Indonesia\% 20Lebi h\%20Banyak\% 20dari\% 20Perempuan\%2

$\%$ 20Ini\% 20Datanya,82\% 20persen\% 20dibanding\%2 0tahun\% 20lalu.)

Adapun Pasal yang terdapat di dalam Undang Undang RI nomor 1 tahun 1974 tentang Perkawinan yang berhubungan dengan ketentuan poligami dapat dilihat dibawah ini :

\section{Pasal 3}

(1) Pada asasnya seorang pria hanya boleh memiliki seorang isteri.Seorang wanita hanya boleh memiliki seorang suami.

(2) Pengadilan, dapat memberi izin kepada seorang suami untuk beristeri lebih dari seorang apabila dikendaki oleh pihak-pihak yang bersangkutan.

\section{Pasal 4}

(1) Dalam hal seorang suami akan beristri lebih dari seorang, sebagaimana tersebut dalam pasal 3 ayat (2) Undang-undang ini, maka ia wajib mengajukan permohonan ke Pengadilan di daerah tempat tinggalnya.

(2) Pengadilan dimaksud dalam ayat (1) pasal ini hanya memberi izin kepada suami yang akan beristri lebih dari seorang apabila:

a. istri tidak dapat menjalankan kewajibannya sebagai isteri;

b. istri mendapat cacat badan atau penyakit yang tidak dapat disembuhkan;

c. istri tidak dapat melahirkan keturunan.

\section{Pasal 5}

(1) Untuk dapat mengajukan permohonan ke Pengadilan sebagaimana dimaksud dalam pasal 4 ayat (1) Undang-undang ini harus memenuhi syaratsyarat berikut: 
a. adanya persetujuan dari isteri/isteri-isteri;

b. adanya kepastian bahwa suami mampu menjamin keperluan-keperluan hidup isteriisteri dan anak-anak mereka.

c. adanya jaminan bahwa suami akan berlaku adil terhadap isteri-isteri dan anak-anak mereka.

Kitab Suci Al Qur'an

Surat Annisa ayat 3

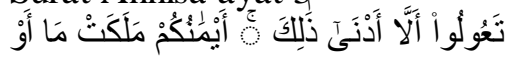

Referensi: https $/ /$ tafsirweb.com/1535-

quran-surat-an-nisa-ayat-3.html

Terjemah Arti: Dan jika kamu takut tidak akan dapat berlaku adil terhadap (hak-hak) perempuan yang yatim (bilamana kamu mengawininya), maka kawinilah wanita-wanita (lain) yang kamu senangi: dua, tiga atau empat. Kemudian jika kamu takut tidak akan dapat berlaku adil, maka (kawinilah) seorang saja, atau budak-budak yang kamu miliki. Yang demikian itu adalah lebih dekat kepada tidak berbuat aniaya.

(Referensi: $\quad$ https $/ /$ tafsirweb.com/1535quran-surat-an-nisa-ayat-3.html)

Di dalam hukum positif di Indonesia, UU nomor 1 tahun 1974 tentang Perkawinan merupakan satu-satu nya rujukan dalam segala hal yang berkaitan dengan pernikahan resmi dan sah. Menurut UU nomor 1 tahun 1974 tentang perkawinan, seorang suami wajib ijin dari istri-istri sebelumnya apabila seorang laki-laki ingin melakukan praktek poligami. Di tengah maraknya kasus perceraian di berbagai daerah di Indonesia, sudah dapat dipastikan terdapat begitu banyaknya wanita yang mendambakan dan memperoleh suami baru yang mapan secara finansial, karena faktanya di masa sekarang sulit mencapai keluarga yang sakinah, mawaddah dan warohmah apabila faktor ekonomi tidak memadai karena kebutuhan sandang, pangan dan papan adalah hal yang tidak bisa ditawar-tawar lagi.

Lelaki yang sudah mapan atau sangat mapan secara ekonomi, fakta di lapangan adalah mayoritas adalah lelaki yang sudah mempunyai istri, sehingga sangat jarang lelaki yang belum menikah ( sekitar usia dibawah 30 thn) sudah mapan secara finansial kecuali mendapat harta dari orang tuanya. Fakta di lapangan juga ditemui bahwa hampir semua wanita tidak mengijinkan suami nya untuk menikah kembali dengan wanita lain dengan berbagai alasan apapun meski suaminya sudah sangat mapan secara finansial.

Orang tua dari janda/duda baru sebagai hasil dari kasus perceraian yang marak di masa pandemi covid 19 akan menemui masalah baru dengan menghidupi dan memberi makan minum anaknya kembali yang sudah menjadi janda, karena sudah bercerai dengan suaminya. Di saat sekarang pun, janda sebagai hasil perceraian sebelum adanya pandemi covid 19 juga sudah sangat banyak, sehingga perlu pemikiran bersama agar tidak melakukan hal-hal yang tidak diinginkan seperti menjadi Oknum mengganggu ketertiban umum dan lain-lain. Tugas pemerintah baik di tingkat pusat ataupun di tingkat daerah sudah tentu menyejahterakan rakyatnya, namun di sisi lain partisipasi dari masyarakat juga diperlukan .

Tingkat kedewasaan masyarakat di era digitalisasi dan teknologi sekarang sudah jauh lebih baik daripada di era -era masa lalu ketika digitalisasi belum berkembang, sehingga segala informasi di luar negeri dapat diketahui secara cepat dan mudah, termasuk klausul praktek poligami di negara-negara yang berpenduduk mayoritas muslim. Dalam ketentuan poligami di Surat Annisa ayat 3 Kitab Suci Al Qur'an, faktanya tidak ada satupun ayat yang mewajibkan seorang laki-laki laki wajib meminta izin dari istrinya untuk melakukan poligami, dan hanya dituntut mampu berlaku adil yang tentunya hal tersebut bersifat relative.

Praktek praktek prostitusi online seperti yang sering kita lihat di berbagai media, secara langsung ataupun tidak langsung juga sebagai akibat dari penerapan UU no.1 tahun 1974 tentang perkawinan khususnya di pasal 3 dan pasal 5, dikarenakan si pelaku khawatir melanggar pasal-pasal tersebut yang sudah tentu berpengaruh terhadap karier yang bersangkutan, dan belum lagi apabila memasukkan unsur dosa dalam agama apapun. Oleh karenanya, terjadi kerancuan selama ini bagi umat Islam di Indonesia, ketika ketentuan pasal 3 dan pasal 5 UU nomor 1 tahun 1974 tentang perkawinan dianggap jauh lebih sakral dan lebih penting daripada ketentuan pada surat Annisa ayat 3 di Kitab Suci Al Qur'an yang merupakan Ketentuan tertinggi bagi umat Islam di seluruh dunia, sehingga hal ini seyogyanya harus diselaraskan, ter khusus di tengah maraknya kasus kasus perceraian pada situasi pandemi seperti sekarang ini

\section{Kesimpulan}

Kegiatan Abdimas ini menghasilkan kesimpulan bahwa berdasarkan hasil kajian dari narasumber dan peserta Webinar, perubahan beberapa pasal di dalam Undang-Undang nomor 1 tahun 1974 yang berkaitan dengan syarat-syarat poligami bagi seorang laki-laki muslim ,perlu untuk dapat diubah sesuai perkembangan zaman. Hal lain yang menjadi hasil dari kegiatan abdimas yaitu menghasilkan kesepahaman bahwa peran negara dalam mengeluarkan sebuah Undang-Undang juga harusnya tidak bertentangan dengan ketentuan agama dari setiap warga negara nya. Kesimpulan ini tentunya berkaitan dengan wajib patuhnya seseorang 
dengan ketentuan di dalam Kitab Suci Agama nya masing-masing , dan negara dalam membuat ketentuan harus selaras dan tidak mengada-ada dalam membuat sebuah aturan yang menambah aturan dalam kehidupan sosial masyarakat, serta tidak ada sama sekali di dalam ketentuan kehidupan ber Agama seseorang, sehingga membuat kesulitan di kemudian hari kepada masyarakat itu sendiri. Oleh karena itulah, secara khusus hasil kegiatan abdimas Webinar ini mengharapkan Negara tidak perlu jauh ikut campur dalam kehidupan sosial yang sudah diatur dalam Kitab Suci masing masing agama dari segenap Warga Negara

\section{Daftar Pustaka}

Abdurahman, A. (1993). Ensiklopedia Ekonomi Keuangan Perdagangan, Jakarta, Pradnya Paramita.

DETIK NEWS 28 AGUSTUS 2020, https://news.detik.com/berita/d5150980/perceraian-di-pulau-jawameningkat-gegara-pandemi-covid-19.

https $/ /$ ayobandung.com/read/2020/09/08/127042/pe rceraian-di-jabar-tinggi-selama-pandemikomunikasi-jadi-sorotan.

https $/ /$ www.solopos.com/penduduk-laki-lakiindonesia-lebih-banyak-dari-perempuan-ini.

Undang-Undang nomor 1 tahun 1974 tentang Perkawinan. 